\title{
A Conceptual Study on Role of Trikantakadi Kwath in Mutrakrichhra
}

\author{
Dr. Shivani Sundriyal ${ }^{1}$, Dr. Sanjay Kumar Tripathi ${ }^{2}$, Dr. Shweta Gyanendra Shukla ${ }^{3}$ \\ ${ }^{1}$ Pg Scholar $2{ }^{\text {Nd }}$ Year. PG Department of Kayachikitsa Rishikul Campus Haridwar \\ ${ }^{2}$ Professor \& Head, PG Department of Kayachikitsa, Rishikul Campus Haridwar \\ ${ }^{3}$ Professor, PG Department of Kayachikitsa Rishikul Campus Haridwar
}

\begin{tabular}{ll}
\hline ARTICLE INFO & ABSTRACT \\
\hline $\begin{array}{l}\text { Published Online: } \\
\text { 09 April 2021 }\end{array}$ & $\begin{array}{l}\text { Nowadays its commonly seen that majority of the people are affected from urinary disorder that may } \\
\text { be due to their lifestyle, diet pattern, low water intake, using western toilet habit, contaminated water, } \\
\text { anatomical anomalies and metabolic derangements. In Ayurveda urinary disorders comes under } \\
\end{array}$ \\
& $\begin{array}{l}\text { Mutrvahasrotasa and describe in the form of Mutrakricchra and Mutraghata. In both of the form } \\
\text { in the form of pain during before and after micturition that manifest in form of burning, tingling and } \\
\text { stinging of urethra. Urinary disorders have become most common cause of morbidity and when } \\
\text { further increases cause renal damage. Though the use of antibiotics has resolved the problem but } \\
\text { relapses resistance and side effects are also associated with their long-term use. Now the need of } \\
\text { Ayurvedic medicine arises to fill this lacuna. There are number of preparations described in } \\
\text { Ayurveda text and trikantakadi kwath in one among them and it has wonderful propertiese that helps } \\
\text { in curing mutrakrichhra. }\end{array}$ \\
Corresponding Author: &
\end{tabular}

KEYWORDS: Vibandha, Sthan Sansrya, Basti

\section{INTRODUCTION}

Ayurveda it is considered that Mutra is formed from Kitta bhaag of Ahara by the action of Jathragni. In Ayurveda urinary disorders comes under Mutrvahasrotasa and describe in the form of Mutrakricchra and Mutraghata. Acharya Vagbhatt has classically divided the Rogas of Mutra in into two categories viz. Mutra Apravartijanya, and Atipravartijanya. Mutrakrichhra comes under category of Mutra Apravartijanya.

In Mutrakrichhra it is consider that Doshas being aggravated by their repetitive etiological factors, individually or all reaches Basti and Mutramarga result in Sthan Sansrya and Vyadhi is produced having cardinal feature as "मूत्रस्य कृछ्रेण महता दुखेन प्रवृति:"। 1

Our dietary pattern which has become enriched with refined flour lacking in dietary fibres sedentary lifestyle, using public toilet, western toilet habit, unprotected sexual activity, immunocompromised state all they have contributed in increasing prevalence of Mutrakrichhra among the society.
This article explains the role of Trikantakdi kwath in the treatment of Mutrakrichhra and its mechanism of action.

\section{MATERIAL AND METHODS}

For this article literature review is done from Charak Samhita, Sushruta Samhita, Madhva nidan, Chakradutta, Bhavaprakash Nighnatu, Ayurvedic pharmacopia of India and few other articles.

\section{Nidana of Mutrakrichhra: ${ }^{2}$}

In Ayurveda it's being considered that
1. Atyadhik vyayam
2. Teekshan aushadha sevan
3. Ruksha madya sevan
4. Excessive indulgence in sexual activity
5. Excess travelling
6. Excess Anupa mansa sevan, eating fishes
7. Adhyasana, Ajeerna 
"A Conceptual Study on Role of Trikantakadi Kwath in Mutrakrichhra"

Samprapti of Mutrakrichhra ${ }^{3}$

Vyayam, Teekshan aushad, Ruksa madya,

Prasang, Nitya druta yana, Vata pradhan ahara,

Vega dharan

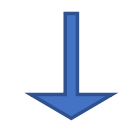

Samana vayu and Pakwashyagat vata prakopa

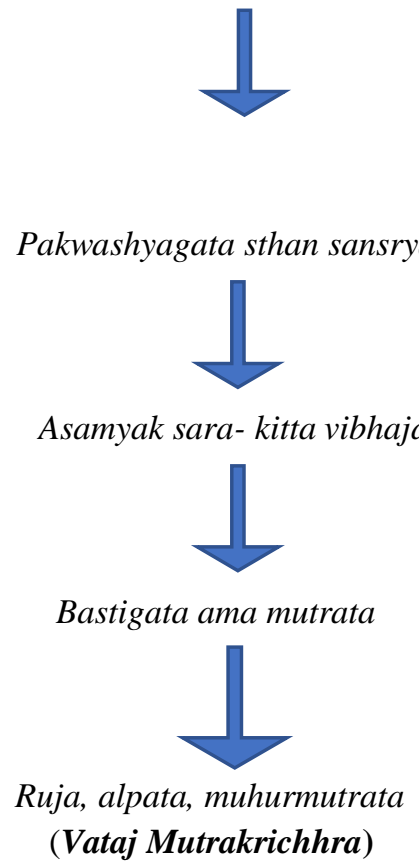

(Vataj Mutrakrichhra)
Daha, ruja peeta mutrata

(Pittaj mutrakrichhra)
Anoopa mansa, adhyasana

Ajeerna

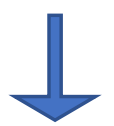

Agnimandya

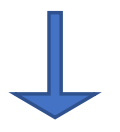

Sama kapha-pitta utpatti

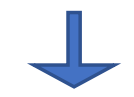

Srotoavrodh

\section{Content of Trikantakadi Kwath:4}

त्रिकंटकारग्वधदर्भकाशदुरालभापर्वतभेदपश्याः।

निघ्नन्ति पीता मधुनाऽश्मरीं च सम्प्राप्तमृत्योरपि मूत्रकृच्छ्र् ॥

1. Trikantaka (Tribulus terrestris), Zygophyllaceae

2. Araghvadha (Cassia fistula), Leguminosae

3. Darbha (Imperata cylindrica), Graminae

4. Kasa (Sacchrum spontaneum), Graminae

5. Duralabha (Alhagi camelorum), Graminae
6. Pashanbheda (Saxifraga ligulata), Saxifragaceae

7. Haritaki (Terminalia chebula), Combretaceae

8. Madhu

Description of each drug will be explained further on the basis of properties, chemical constituents, action of dosha, pharmacological action

Table $^{5}$

\begin{tabular}{|l|l|l|l|l|l|l|l|}
\hline Drug & Rasa & Guna & Virya & Vipaka & $\begin{array}{l}\text { Dosha } \\
\text { Karma }\end{array}$ & $\begin{array}{l}\text { Pharmacological } \\
\text { Action }\end{array}$ & $\begin{array}{l}\text { Chemical } \\
\text { constituents }\end{array}$ \\
\hline Gokshur & Madhura & $\begin{array}{l}\text { Guru, } \\
\text { Snigdha }\end{array}$ & Sheeta & Madhura & $\begin{array}{l}\text { Vata-pitta } \\
\text { Shamak }\end{array}$ & $\begin{array}{l}\text { Diuretic } \\
\text { Anti-inflammatory } \\
\text { Aphrodisiac }\end{array}$ & $\begin{array}{l}\text { Harman,sterols,sapo } \\
\text {-genin } \\
\text { diosgenin, gitogenin }\end{array}$ \\
\hline Araghvadha & Madhura & $\begin{array}{l}\text { Guru, } \\
\text { Snigdha }\end{array}$ & Sheeta & Madhura & $\begin{array}{l}\text { Tridosh- } \\
\text { Hara }\end{array}$ & $\begin{array}{l}\text { Laxative, } \\
\text { Anti-inlammatory } \\
\text { Carminative, }\end{array}$ & $\begin{array}{l}\text { Sugar,mucilage, } \\
\text { pectins, } \\
\text { anthraquinone }\end{array}$ \\
\hline Darbha & Madhura & $\begin{array}{l}\text { Laghu, } \\
\text { Snigdha }\end{array}$ & Sheeta & Madhura & $\begin{array}{l}\text { Tridosh- } \\
\text { Hara }\end{array}$ & $\begin{array}{l}\text { Diuretic, } \\
\text { Astringent }\end{array}$ & $\begin{array}{l}\text { Cylindrin, arundoin, } \\
\text { fernenon, isoburneol } \\
\text { simiarenon. }\end{array}$ \\
& & & & & & \\
\hline
\end{tabular}


"A Conceptual Study on Role of Trikantakadi Kwath in Mutrakrichhra"

\begin{tabular}{|l|l|l|l|l|l|l|l|}
\hline Kasa & Madhura & Sara & sheeta & Madhura & Pitta-Hara & $\begin{array}{l}\text { Diuretic, } \\
\text { Immunomodulator, }\end{array}$ & $\begin{array}{l}\text { Galactose, } \\
\text { rhamnose, terpenes, } \\
\text { coumarins, }\end{array}$ \\
\hline $\begin{array}{l}\text { Paashanbhe } \\
\text { da }\end{array}$ & $\begin{array}{l}\text { Kashaya, } \\
\text { Tikta }\end{array}$ & $\begin{array}{l}\text { Laghu, } \\
\text { Snigdha, } \\
\text { Tikshana }\end{array}$ & Ushna & Katu & $\begin{array}{l}\text { Tridosh- } \\
\text { Hara }\end{array}$ & $\begin{array}{l}\text { Diuretic, } \\
\text { lithotriptic, } \\
\text { Antinflammatory }\end{array}$ & $\begin{array}{l}\text { Tannic acid, gallic } \\
\text { acid }\end{array}$ \\
\hline Haritaki & $\begin{array}{l}\text { Kashaya, } \\
\text { Amla } \\
\text { Tikta, } \\
\text { Katu } \\
\text { Madhura, } \\
\text { Ruksha }\end{array}$ & Ushna & Madhura & $\begin{array}{l}\text { Tridosh- } \\
\text { Hara }\end{array}$ & $\begin{array}{l}\text { Anti-bacterial, } \\
\text { Antiinflammatory, } \\
\text { Hepatoprotective }\end{array}$ & $\begin{array}{l}\text { Tannins, } \\
\text { anthraquinones, } \\
\text { polyphenols }\end{array}$ \\
\hline Yavasa & $\begin{array}{l}\text { Madhura, } \\
\text { Tikta, } \\
\text { Kashaya }\end{array}$ & $\begin{array}{l}\text { Guru, } \\
\text { Snigdha }\end{array}$ & Sheeta & Madhura & $\begin{array}{l}\text { Pitta- } \\
\text { Kapha } \\
\text { Hara }\end{array}$ & $\begin{array}{l}\text { Antacid, } \\
\text { Laxative, Diuretic, } \\
\text { Gastroprotective }\end{array}$ & $\begin{array}{l}\text { B-phenethylamine, } \\
\text { Salsolidine,Betaline, } \\
\text { Sterols, Coumarins }\end{array}$ \\
\hline
\end{tabular}

Probable mode of action on Samprapti Vighatan ${ }^{7}$ :

\begin{tabular}{|l|l|l|}
\hline Samprapti ghataka & Mutrakrichhra & Treatment \\
\hline Dosha & Tridosha & Tridoshaghna \\
\hline Dushya & Mutra & Mutrala \\
\hline Agni & Mandya & Deepana, pachana \\
\hline Srotas & Mutravahasrotasa & Mutrala \\
\hline Udbhava sthana & Amashaya and pakvashaya & Samyak sara kitta vibhajana \\
\hline Adhishtana & Basti and mutravahasrotasa & Mutrala \\
\hline Vyakta sthana & Basti and mutravahasrotasa & Mutrala \\
\hline Dushtiprakarana & Sanga & Chedana, bhedana, lekhana \\
\hline
\end{tabular}

Gokshura contains nitrates and oils, which causes diuresis and due to its vata pitta shamak action it can be used to reduce inflammation and pain in conditions where some stone produces obstruction and infections leading to colicky pain. It has maximum amount of potassium and other alkaloids due to which it acts as a loop diuretic.

Araghvadha is having sukha virechaka propertiese as mentioned in agrya prakaran of Charak Samhita that helps is removal of morbid pitta, and anulomana of apana vata which helps in mutranishkramana it is also having antibacterial and antifungal propertiese against some gram positive staphylococcus aureus and streptococcus pyogenes, some gram neagative E.Coli, ${ }^{8}$ Pseudomonas aeruginiosa, antifungal strains Aspergillus niger, Candida albicans and results were remarkably comparable with that of ampicillin, ciprofloxacin, norfloxacin and chloramphenicol and this data is available in one of the renowned journal.

Darbha is having Tridoshaghna gunas according to acharya Bhavamishra. In Kaideva Nighantu also its mentioned as ashmarihara and basti vikarahara and according to rasa which is madhura and kashaya its mainly used as an astringent. Apart from this there are some thesis work available showing result of trinapanchmoola drugs in chronic renal failure ${ }^{9}$, renal proteinuria ${ }^{10}$.

Haritaki due to Kashaya rasa it has sanshaman, kapha soshan, shareerasya kledasya upyokta kapha-rakta-pitta prashman gunas, due to amla rasa got vata anulomaka propertiese, katu rasa margaan vivrunoti. It also has prokinetic action antibacterial action against Salmonella typhi, ${ }^{11}$ Staphylococcus epidermidis Staphylococcus aureus, Bacillus subtilis that also have been proven in another journal. Paashanbheda has tridoshaghna and mutravirechaniya and ashmarighna propertiese ${ }^{12}$.

Duralabha is having pitta pacifying propertiese kapha hara gunas and diuretic action.

\section{DISCUSSION}

Finally, we can say on the basis of description of these drugs that they have following properties i.e. vata-pitta shamak, mutrala, anulomak, mutrakrichhra hara, daha shamak, ashmari hara, srotoshodhak, vranropak propertiese.

On modern parameters we can say that these drugs have antiinflammatory, diuretic, antacid lithotriptic, anti-lithogenic, laxative actions.

\section{CONCLUSION}

Ayurveda is a medical branch giving utmost preference in correcting the physiological aspects of mutrakricchra. The vivid Ayurvedic vocabulary is capable of addressing issues like mutrakricchra to a great extend and can really contribute to the whole medical world by providing alternative for antibiotics and chemically made alkalisers. Modern pharmacological agents are having their own limitations as per reported studies. The holistic approach which should include dietary factors, physical, and environmental factors is necessary to prevent incidence of mutrakrichhra and large 
number of ayurvedic medicines are available whom we should recognise and put evidence based research proving that use of these drugs will be worthwhile in treating urinary disorders and avoiding further complication in the form of chronic kidney disease.

\section{REFERENCES}

1. Madhav Nidan with Madhukosh Sanskrit Commentary by Shri Vijayraksita \& Shri Kanthadatta with Vidyotini Hindi Commentary revised \&edited by Prof. Yadunandan Upadhyaya, Part-1, Chaukhambha Prakashan, Varanasi Mutrakrichhra nidana adhyaya 30, page nmb 55.

2. Madhav Nidan with Madhukosh Sanskrit Commentary by Shri Vijayraksita \& Shri Kanthadatta with Vidyotini Hindi Commentary revised \&edited by Prof. Yadunandan Upadhyaya, Part-1, Chaukhambha Prakashan, Varanasi Mutrakrichhra nidana adhyaya 30page nmb 551

3. Negi Bhavya: To study the effect of Gokshur in Mutrakrichhra of pregnancy, 2019, Rishikul Campus Haridwar thesis work

4. Chakradatta,Vaidyaprabha , Hindi commentary, Dr.Indradev Tripathi, Chaukhambha Sanskrit Sansthan, Varanasi,Reprint 2005 adhyaya 32/22

5. Ayurvedic Pharmacopia of India, Textbook of medicine, editor-in chief YP Munjal, 9th edition 2012, Jaypee brother.
6. Dravya Guna Vigyan, Acharya Priyavrat Sharma, Vol II, Chaukhambha Bharti Academy Reprint 2011

7. Susruta Samhita, volume 1 nidansthana chapter3, edited with 'sushrutavimarshini' hindi commentary by Dr.Anant Ram Sharma, chukhambha Shubharati Prakashan, Varansai, reprint 2013.

8. Nayan R. Bhalodia and V.J Shukla: Antibacterial and Antifungal activitiese fron cassia fistula: an ethnomedicinal plant, J adv Pharm Technol Res. 2011 Apr-Jun, 2: 104-109.

9. The study of Trinpanchmula decoction on patient of mutraghata with special reference to chronic renal failure PG Department of kayachikitsa lucknow 1983.

10. Bahukhandi OP: to study the effect of trinpanchmuladi kwath in patient of shuklameha with special Reference to renal proteinuria (a clinical and experimental study), PG department of kayachikitsa lucknow 1986.

11. Kannan P, Ramadevi S.R and Hopper W: antibacterial activity of Terminalia Chebula frit extract, African journal of microbiology research, April 2009, vol 3 (4) pp. 180-184.

12. Bhavaprakash Nighantu, haritakyadi varga, pashanbheda, shlok 184-185, by Dr K.C Chunekar, Chaukhambha surbharati prakashan, Varanasi reprint 2004. 